\title{
ETNOMATEMATIKA HADRAH AL-BANJARI SEBAGAI BASIS MASALAH OPEN-ENDED
}

\author{
Rido Dwi Setiyawan $^{1}$, Rachmaniah Mirza Hariastuti ${ }^{2}$ \\ Pendidikan Matematika, Universitas PGRI Banyuwangi ${ }^{1,2}$ \\ ridodwisetiyawan97@gmail.com ${ }^{1}$
}

\begin{abstract}
ABSTRAK
Open-Ended merupakan suatu bentuk masalah yang diformulasikan dengan lebih dari satu penyelesaian. Pemberian masalah Open-Ended, khususnya pada mata pelajaran matematika di sekolah dipandang perlu dilakukan. Hal ini dikarenakan masih terdapat siswa yang belum mampu mengkoneksikan konsepkonsep matematika dengan kehidupan sehari-hari, salah satunya dengan budaya. Etnomatematika merupakan matematika yang dipraktikkan dalam kelompok budaya yang diidentifikasi sebagai masyarakat nasional, suku, kelompok buruh, anak-anak dari kelompok usia tertentu serta kelas profesional. Hadrah AlBanjari adalah salah satu budaya yang berkembang di Banyuwangi. Budaya ini memuat beragam konsep matematika yang menarik untuk dijadikan basis penyusunan masalah Open-Ended. Keliling dan luas lingkaran merupakan konsep matematika dalam Hadrah Al-Banjari yang dapat diaplikasikan pada masalah Open-Ended. Masalah ini diujikan pada tiga orang siswa kelas VII di SMP Negeri 1 Glagah Banyuwangi. Metode pengumpulan data dilakukan dengan tes dan wawancara. Analisis data dilakukan secara kualitatif berdasarkan indikator yang telah ditetapkan. Hasil analisis menunjukkan bahwa ketiga subyek mampu mengidentifikasi unsur-unsur yang diketahui dan ditanyakan dari soal, membuat dan menyusun model matematika dari masalah yang diberikan dengan satu ide atau gagasan, menyusun minimal tiga strategi atau pendekatan untuk menyelesaikan masalah, dan menjelaskan hasil penyelesaian masalah sesuai permasalahan awal dengan kalimat sendiri.
\end{abstract}

Kata kunci : open-ended, etnomatematika, lingkaran

\begin{abstract}
An open-ended problem is one that is posed with more than one solution. It is considered necessary to assign open-ended problems in school, especially in mathematics. This is due to the fact that some students are still unable to relate mathematical concepts to real life, one of which is culture. Ethnomatematics is mathematics that is practiced in cultural groups identified as national societies, ethnic groups, labor groups, children from certain age groups, and professional classes. One of the cultures that originated in Banyuwangi is Hadrah AlBanjari. This culture includes a number of intriguing mathematical ideas that can be used to formulate Open-Ended problems. In Hadrah Al-Banjari, the diameter and area of a circle are mathematical principles that can be extended to Open-Ended problems. Three grade VII students from SMP Negeri 1 Glagah Banyuwangi were tested on this topic. Data was gathered by the use of tests and interviews. The data was analyzed qualitatively using predetermined indicators. The study findings show that the three subjects can classify the elements that are known and asked of the questions, construct and compile a mathematical
\end{abstract}


model of the problem provided with one idea or idea, produce at least three solutions or approaches to solving the problem, and describe the problemsolving results with their sentences.

Keywords : open-ended, ethnomathematics, circle

\section{PENDAHULUAN}

Matematika merupakan salah satu mata pelajaran yang memiliki peran penting dalam kehidupan manusia. Banyak hal dalam kehidupan sehari-hari yang melibatkan konsep-konsep matematika, seperti pengukuran dalam proses pembangunan, jualbeli, perbandingan dalam pembuatan resep, dan lain-lain. Pembelajaran matematika yang berkualitas dengan tujuan untuk memberi bekal pada siswa tentang kemampuan menyelesaikan masalah; merancang model matematika; serta menyelesaikan model dan menafsirkan solusi yang diperoleh, menunjukkan bahwa penyelesaian masalah masih menjadi suatu bentuk kemampuan yang diharapkan dari siswa setelah pembelajaran matematika (Sa'diah, 2019). Penelitian Mairing (2016) memberikan hasil $97,22 \%$ siswa tidak tergolong sebagai penyelesai masalah yang baik, dan kondisi tersebut perlu diperbaiki dengan menghadapkan siswa pada masalah matematika di kelas. Sedangkan penelitian Rianti (2018) pada siswa kelas VIII-5 SMP Negeri 6 Siak Hulu menunjukkan bahwa nilai kemampuan penyelesaian masalah matematis siswa berkemampuan tinggi berada pada kategori cukup sebesar $61,11 \%$, siswa berkemampuan sedang berada pada kategori kurang sebesar 42,78 \%, dan siswa berkemampuan rendah berada pada kategori sangat kurang sebesar 24,44 $\%$.

Barca menyatakan bahwa kemampuan penyelesaian masalah sangat penting dimiliki oleh setiap siswa karena merupakan tujuan umum pembelajaran matematika, proses inti dan utama dalam kurikulum matematika, dan kemampuan dasar dalam belajar matematika (Sumartini, 2016). Ruseffendi mendukung pendapat tersebut dengan menyampaikan bahwa pemecahan masalah amat penting dalam mendalami atau mempelajari matematika di kemudian hari, serta dibutuhkan sebagai penerapan dalam mata pelajaran lain dan kehidupan sehari-hari (Yuwono, Supanggih, dan Ferdiani, 2018). Adapun penyelesaian masalah dapat dilakukan dengan empat langkah, yaitu : (1) memahami masalah; (2) membuat rencana penyelesaian berdasarkan hubungan berbagai komponen masalah; (3) melaksanakan rencana; dan (4) mengecek kembali penyelesaian yang telah diperoleh (Polya, 1973).

Masalah dalam matematika diharapkan dapat membuat siswa merasa tertantang untuk menyelesaikan dengan beragam cara. Hal ini sesuai dengan yang disampaikan oleh Polya bahwa masalah matematika adalah soal yang menantang dengan cara penyelesaian yang tidak segera dapat dilihat oleh siswa dan dapat dikonstruksi dalam berbagai bentuk (Mairing dan Aritonang, 2018). Penyelesaian masalah dalam matematika dapat disajikan dalam berbagai bentuk, salah satunya adalah open-ended. Becker dan Shimada menyatakan bahwa open ended merupakan penyajian suatu masalah yang memiliki penyelesaian lebih dari satu strategi atau memiliki lebih dari satu jawaban yang benar (Suryanovan, 2014; Syutaridho, 2015).

Pemberian soal open-ended memungkinkan siswa berperan aktif dalam mengembangkan metode penyelesaian masalah tanpa harus terpaku pada cara yang sudah biasa dikenal sebelumnya (Mustikasari, Zulkardi, dan Aisyah, 2010). 
Munandar menyebutkan bahwa siswa dikatakan mampu menyelesaikan soal openended jika memenuhi kriteria : (1) kelancaran berpikir (fluency), yaitu kemampuan untuk menghasilkan banyak ide/gagasan; dan (2) keluwesan (flexibility), yaitu kemampuan untuk mengajukan bermacam macam pendekatan atau jalan pemecahan terhadap permasalahan (Djahuno, 2015).

Masalah open-ended dapat dibuat berdasarkan hal-hal yang dekat dengan kehidupan sehari-hari siswa. Salah satu hal yang dekat dengan kehidupan siswa adalah budaya. Budaya memuat berbagai konsep-konsep matematika yang secara umum tidak disadari oleh pelaku budaya tersebut. D'Ambrosio menyebutkan bahwa etnomatematika merupakan matematika yang dipraktikkan dalam kelompok budaya yang diidentifikasi sebagai masyarakat nasional, suku, kelompok buruh, anak-anak dari kelompok usia tertentu serta kelas profesional (Putri, 2017). Selain itu D'Ambrosio juga menyatakan bahwa etnomatematika merupakan pendekatan dalam pembelajaran matematika yang terbentuk dari pengetahuan, latar belakang, aturanaturan yang berlaku di masyarakat, serta pengalaman masa lampau siswa yang telah dipraktikkan (Hariastuti, Budiarto, dan Manuharawati, 2020). Sehingga dirasa sesuai untuk mengintegrasikan budaya dalam masalah-masalah matematika yang diberikan pada siswa.

Salah satu bentuk budaya yang dikenal oleh siswa di Banyuwangi adalah Hadrah Al-Banjari (memiliki sebutan lain di daerah yang berbeda, seperti marawis dan sebagainya). Hadrah Al-Banjari adalah kesenian yang dimainkan dengan setiap pukulan antar pemain berbeda namun saling melengkapi dan membentuk harmoni bermusik (Machrus, 2014; Khoiri, 2019). Sedangkan Ramadhani (2019) menyatakan bahwa Hadrah Al-Banjari merupakan kesenian Islami yang dimainkan oleh beberapa orang dengan alat musik rebana dengan ketentuan-ketentuan tertentu.

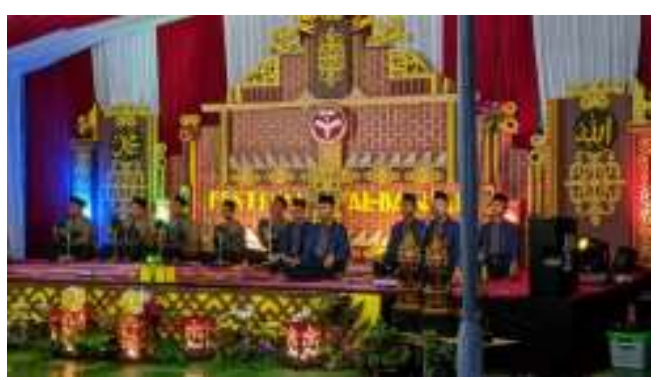

Gambar 1. Kesenian hadrah al-Banjari di Banyuwangi

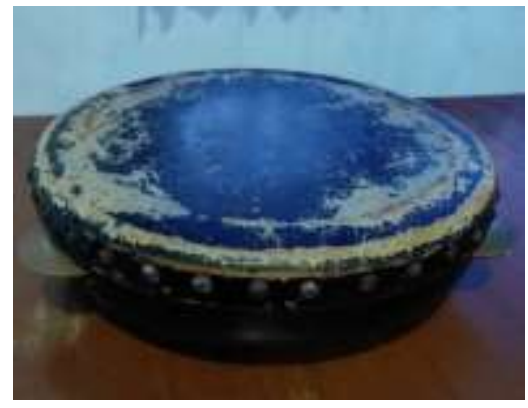

Gambar 2. Rebana dalam kesenian hadrah al-Banjari 
Hasil eksplorasi etnomatematika yang dilakukan oleh Putri (2017) pada rebana menunjukkan adanya konsep geometri seperti lingkaran, tabung dan kerucut, serta teknik membilang untuk membentuk pola nada yang serasi. Sedangkan penelitian Afriyanty dan Izzati (2019) pada kesenian marawis menunjukkan adanya praktik matematika berupa konsep geometri lingkaran, geometri transformasi (translasi dan refleksi), simetri (lipat dan putar), serta sudut (lancip dan tumpul). Kedua penelitian tersebut sama-sama mengindikasikan bahwa konsep lingkaran terdapat dalam rebana (alat musik yang digunakan dalam kesenian Hadrah Al-Banjari). Untuk itu Hadrah Al-Banjari (khususnya rebana) dapat dijadikan basis dalam pengkonstruksian masalah open-ended.

Inprashita menyatakan bahwa pendekatan dengan masalah open-ended dapat meningkatkan kualitas pembelajaran yang dimulai dengan melibatkan siswa dalam masalah terbuka yang diformulasikan untuk memiliki beberapa jawaban yang benar (Nada, 2018). Hal tersebut diperkuat oleh penelitian yang dilakukan oleh Yusliriadi (2015) di SMP Negeri 1 Pangkalpinang kelas IX tentang pengembangan soal OpenEnded pada materi barisan dan deret. Hasil penelitian menunjukkan bahwa produk soal Open-Ended pokok bahasan barisan dan deret bilangan untuk siswa kelas IX SMP yang telah dinyatakan valid dan praktis dapat memberikan efek potensial yang positif terhadap kemampuan pemahaman konsep siswa. Hal ini dapat diketahui dari rata-rata nilai pemahaman konsep siswa pada tes soal Open-Ended mencapai 71,9\%. Selain itu, hasil penelitian tersebut juga menunjukkan bahwa masih ada siswa yang belum mampu memberikan jawaban yang kreatif dalam penyelesaian masalah soal Open-Ended sebesar 28,1\%. Penelitian lain yang dilakukan oleh Ruslan dan Santoso (2013) di kelas VIII SMP Negeri 7 Prabumulih menunjukkan bahwa terdapat perbedaan signifikan dalam peningkatan kemampuan penalaran matematis antara siswa yang diberi soal Open-Ended dan siswa yang diberi soal rutin.

Pembahasan di atas menjadi dasar bahwa belum pernah dilakukan eksplorasi terhadap kemampuan siswa dalam menyelesaikan masalah open-ended berbasis etnomatematika Hadrah Al-Banjari. Penelitian ini penting dilakukan untuk mengetahui respon siswa terhadap penyelesaian masalah yang berhubungan dengan budaya yang dikenal oleh siswa. Adapun etnomatematika dari Hadrah Al-Banjari yang digunakan sebagai basis masalah Open-Ended dibatasi pada keliling dan luas lingkaran.

\section{METODE}

Penelitian ini dilakukan secara kualitatif dengan peneliti bertindak sebagai instrumen utama dibantu instrumen tambahan berupa angket, tes, dan pedoman wawancara. Triangulasi metode dilakukan untuk mengklarifikasi data yang diperoleh untuk selanjutnya dianalisis secara induktif/kualitatif. Penelitian dilakukan mulai bulan Agustus hingga September 2020. Subjek penelitian adalah 3 siswa kelas VIII SMP Negeri 1 Glagah Banyuwangi yang dipilih secara purposive dengan kriteria memiliki kemampuan matematika paling tinggi (berdasarkan perolehan nilai matematika di semua kelas paralel). Selain itu, subjek juga dipilih dengan kriteria komunikatif dalam penyampaian. 
Analisis data dilakukan berdasarkan indikator yang telah ditentukan sesuai dengan tabel 1 .

Tabel 1. Indikator penyelesaian masalah open-ended

\begin{tabular}{|c|c|}
\hline No & Indikator \\
\hline 1 & $\begin{array}{l}\text { Siswa mampu mengidentifikasi unsur-unsur yang diketahui dan } \\
\text { ditanyakan pada masalah yang diberikan dengan kalimat sendiri }\end{array}$ \\
\hline 2 & $\begin{array}{l}\text { Siswa mampu membuat dan menyusun model matematika dari masalah } \\
\text { yang diberikan dengan beragam ide atau gagasan }\end{array}$ \\
\hline 3 & $\begin{array}{l}\text { Siswa mampu menyusun beragam strategi atau pendekatan untuk } \\
\text { menyelesaikan masalah dengan benar }\end{array}$ \\
\hline 4 & $\begin{array}{l}\text { Siswa mampu menjelaskan hasil penyelesaian masalah sesuai } \\
\text { permasalahan awal dengan kalimat sendiri }\end{array}$ \\
\hline
\end{tabular}

Selanjutnya hasil analisis data dideskripsikan sesuai dengan pencapaian kemampuan penyelesaian masalah yang dilakukan siswa. Subjek dikatakan memenuhi indikator (1) jika dapat menuliskan/menyebutkan unsur-unsur yang diketahui dan ditanyakan dari masalah yang diberikan dengan menggunakan kalimatnya sendiri. Subjek dikatakan memenuhi indikator (2) jika dapat menuliskan/menyebutkan minimal dua ide/gagasan penyelesaian masalah. Subjek dikatakan memenuhi indikator (3) jika dapat menuliskan/menyebutkan minimal tiga strategi penyelesaian masalah dengan benar. Subjek dikatakan memenuhi indikator (4) jika dapat menuliskan/menyebutkan penyelesaian dari masalah yang diberikan dengan kalimatnya sendiri.

\section{HASIL DAN PEMBAHASAN}

Penelitian diawali dengan pembuatan instrumen tambahan berupa soal tes dan pedoman wawancara. Instrumen tes memuat 2 soal penyelesaian masalah openended yang terdiri dari konsep keliling dan luas lingkaran. Kisi-kisi tes memuat permasalahan sebagai berikut.

1. Diberikan tiga rebana $A, B, C$ dengan ukuran keliling permukaan yang berbeda, yaitu $A<B<C$. Ukuran jari-jari yang diberikan hanya untuk rebana $B$, sedangkan rebana $A$ dan $C$ dapat ditentukan sendiri. Jika setiap rebana ditutup dengan kulit sapi dan direkatkan dengan paku pines yang dipasang dengan jarak antar paku sebesar $x \mathrm{~cm}$, selanjutnya siswa diminta untuk menentukan banyak paku pines yang dibutuhkan.

2. Seorang peternak sapi memiliki 3 jenis sapi yaitu Limousin, Brahman, dan Angus yang masing-masing memiliki luas kulit sapi yang berbeda. Luas kulit sapi Limousin > luas kulit sapi Brahman > luas kulit sapi Angus. Jika akan dibuat 5 buah alat kesenian hadrah Al-Banjari dengan jari-jari permukaan yang sama, maka siswa diminta untuk menentukan banyak dan jenis sapi yang harus dipotong agar kulitnya dapat digunakan.

Validasi instrumen menunjukkan hasil 47,5, yang berarti instrumen soal tes dinyatakan valid dan dapat digunakan. Pengumpulan data dilakukan secara luring dengan tetap memperhatikan protokol kesehatan. Hasil penelitian diperoleh dalam bentuk dokumen hasil kerja siswa (tertulis) dan rekaman wawancara (yang selanjutnya ditranskrip). 
Gambar 3 menunjukkan penyelesaian tes subjek pertama (S1) pada masalah pertama. Triangulasi hasil tes dengan hasil wawancara menunjukkan bahwa S1 dapat menuliskan dan menyebutkan unsur-unsur yang diketahui dan ditanyakan pada soal. Pada proses tes, S1 tidak menuliskan ide/gagasan penyelesaian masalah, tetapi dapat menyebutkan satu ide dalam proses wawancara.

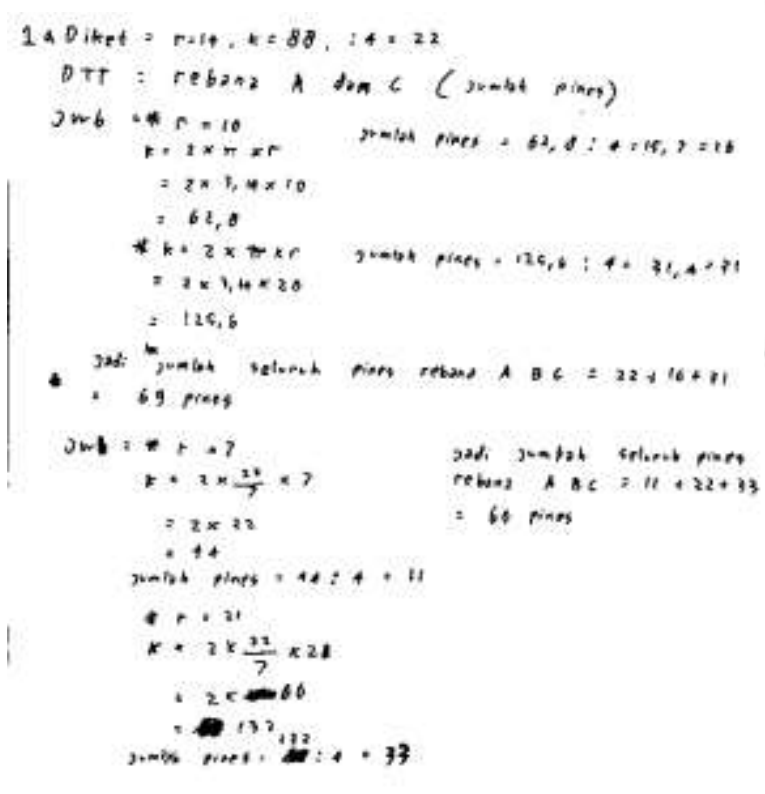

$$
\begin{aligned}
& 2 m b: t=? \\
& 0: 24 \\
& k=\pi x d \\
& =3,4 \times 24 \\
& =75,36 \\
& \text { imbile pines: } 15,16: 4=18,44=19 \\
& r: 30 \\
& 0: 60 \\
& k=\pi \times d \\
& =3,4 \times 60 \\
& : 188,4 \\
& 20 \mathrm{ml}, \mathrm{f} \text {, wine } 18,4: 1: 43,1: 17
\end{aligned}
$$

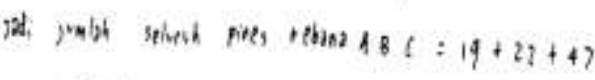

$$
\begin{aligned}
& 287 \text { pines }
\end{aligned}
$$

Gambar 3. Hasil tes S1 pada soal nomor 1

Ide yang diberikan adalah menentukan jari-jari rebana, menghitung keliling rebana, membagi keliling rebana dengan jarak antar paku pines, kemudian menjumlahkan semua kebutuhan rebana. Proses penyelesaian dapat dilakukan dengan 3 strategi, yaitu : (1) menggunakan rebana $A$ dengan jari-jari 10 satuan dan rebana $C$ dengan jari-jari 20 satuan; (2) menggunakan rebana $A$ dengan jari-jari 7 satuan dan rebana $C$ dengan jari-jari 21 satuan; dan (3) menggunakan rebana $A$ dengan jari-jari 7 satuan dan rebana $C$ dengan jari-jari 30 satuan. S1 memilih nilai jari-jari tersebut dengan asumsi dapat menggunakan nilai $\pi=\frac{22}{7}$ atau $\pi=3,14$. Dari ketiga strategi tersebut, S1 kurang teliti pada strategi ketiga sehingga memberikan jawaban yang salah. Diakhir proses tes dan wawancara menunjukkan bahwa S1 dapat menuliskan dan menyebutkan penyelesaian masalah dengan kalimatnya sendiri.

Gambar 4 menunjukkan penyelesaian tes S1 pada masalah kedua. Triangulasi hasil tes dengan hasil wawancara menunjukkan bahwa S1 dapat menuliskan dan menyebutkan unsur-unsur yang diketahui dan ditanyakan pada soal. Pada penyelesaian tes, S1 tidak menuliskan ide/gagasan penyelesaian masalah, tetapi dapat menyebutkan satu ide dalam proses wawancara. Ide yang diberikan adalah menggambar kulit sapi yang diberikan kemudian meletakkan bentuk lingkaran sebagai perwakilan dari hadrah (yang telah ditentukan luasnya). Proses penyelesaian dapat dilakukan S1 dengan menentukan 4 strategi pada tes yaitu penggunaan 3 kulit sapi Brahman, atau 5 kulit sapi Angus, atau 2 kulit sapi Brahman dan 1 kulit sapi Angus, atau 1 kulit sapi Brahman dan 3 kulit sapi Angus. Sedangkan proses 
penyelesaian dalam wawancara memberikan hasil penggunaan 3 kulit sapi Brahman, atau 5 kulit sapi Angus, atau 2 kulit sapi Brahman dan 1 kulit sapi Angus, atau 3 kulit sapi Angus dan 1 kulit sapi Brahman. Di akhir proses tes dan wawancara menunjukkan bahwa S1 dapat menuliskan dan menyebutkan penyelesaian masalah dengan kalimatnya sendiri.
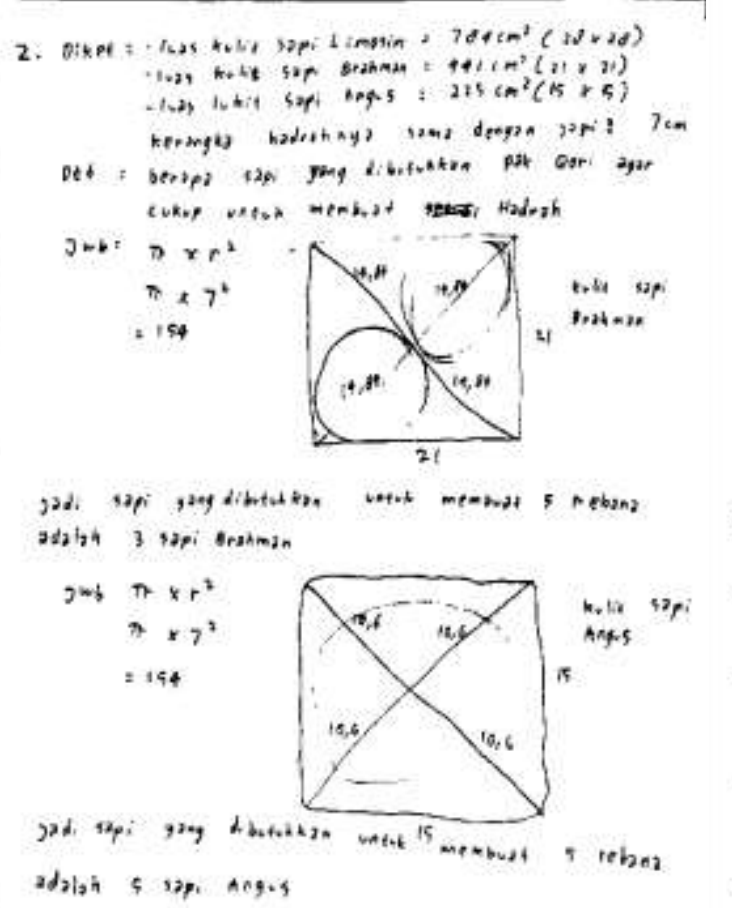

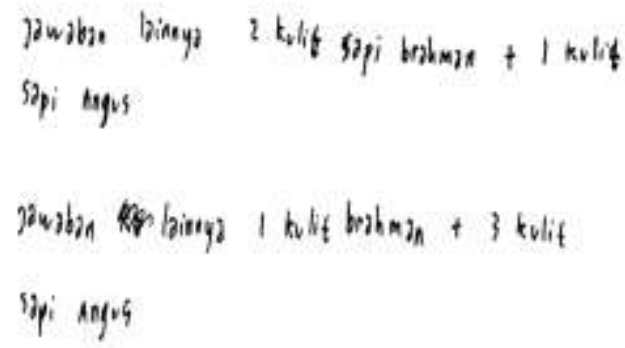

Gambar 4. Hasil tes S1 pada soal nomor 2

Gambar 5 menunjukkan penyelesaian tes subjek kedua (S2) pada masalah pertama. Triangulasi hasil tes dan hasil wawancara menunjukkan bahwa S2 dapat mengidentifikasi unsur-unsur yang diketahui dan ditanyakan dari masalah yang diberikan melalui tes dan wawancara. S2 tidak menuliskan ide yang akan digunakan untuk menyelesaikan masalah dalam penyelesaian tes. Tetapi dalam proses wawancara, S2 dapat menyebutkan satu ide penyelesaian masalah, yaitu menentukan hadrah dengan jari-jari kurang dari dan lebih dari 14 satuan, menghitung keliling permukaan hadrah, membagi nilai keliling dengan jarak antar pines, kemudian menjumlahkan semua banyak pines yang dibutuhkan. Pada proses tes dan wawancara, S2 dapat memberikan 3 strategi penyelesaian, yaitu : (1) menggunakan rebana $A$ dengan jari-jari 7 satuan dan rebana $C$ dengan jari-jari 28 satuan; (2) menggunakan rebana $A$ dengan jari-jari 10 satuan dan rebana $C$ dengan jari-jari 20 satuan; dan (3) menggunakan rebana $A$ dengan jari-jari 5 satuan dan rebana $C$ dengan jari-jari 15 satuan. S2 memilih nilai jari-jari tersebut dengan asumsi dapat menggunakan nilai $\pi=\frac{22}{7}$ atau $\pi=3,14$. Pada tes maupun wawancara, S2 dapat menjelaskan hasil penyelesaian masalah dengan menggunakan kalimat sendiri. 


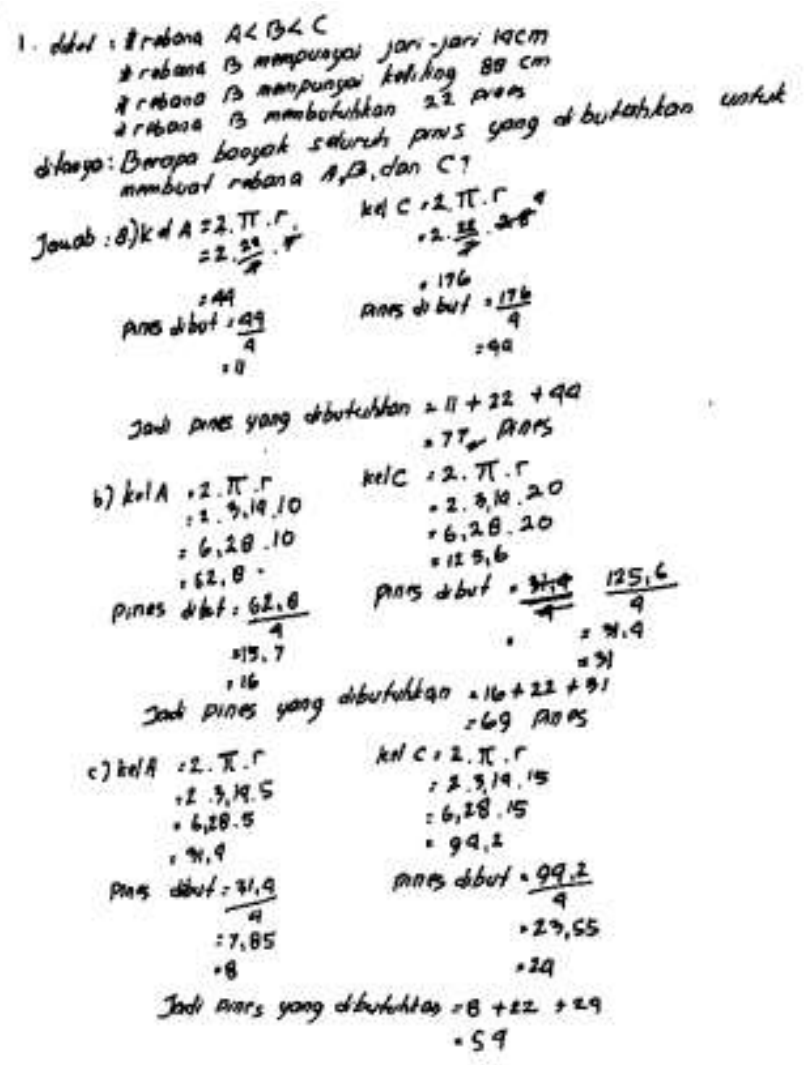

Gambar 5. Hasil tes S2 pada soal nomor 1

Gambar 6 menunjukkan penyelesaian tes S2 pada masalah kedua. Hasil triangulasi penyelesaian tes dan wawancara menunjukkan bahwa S2 dapat mengidentifikasi unsur-unsur yang diketahui dan ditanyakan dari masalah yang diberikan melalui tes dan wawancara. S2 tidak dapat menuliskan ide yang akan digunakan untuk menyelesaikan masalah dalam penyelesaian tes. Tetapi dalam proses wawancara, S2 dapat menyebutkan satu ide penyelesaian masalah, yaitu mencari luas hadrah kemudian menentukan kulit yang cocok dengan hadrah tersebut. Pada penyelesaian tes dan wawancara, S2 dapat memberikan 3 strategi penyelesaian yang sama, yaitu penggunaan 5 kulit sapi Angus, atau 3 kulit sapi Limousin, atau 2 kulit sapi Limousin dan 1 kulit sapi Angus. Pada saat tes maupun wawancara, S2 dapat menjelaskan hasil penyelesaian masalah dengan menggunakan kalimat sendiri. 


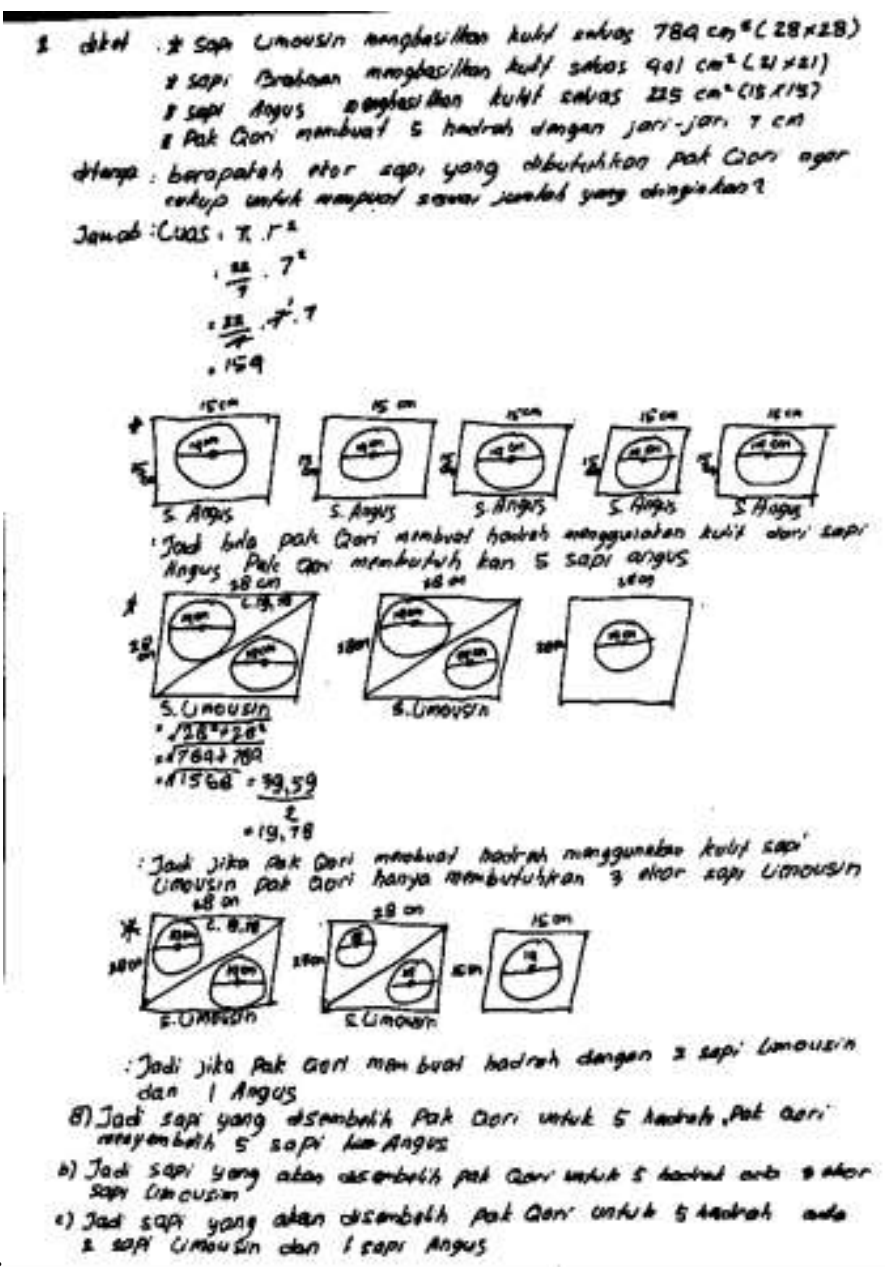

Gambar 6. Hasil tes S2 pada soal nomor 2

Gambar 7 menunjukkan penyelesaian tes subjek tiga (S3) pada masalah pertama. Triangulasi hasil tes dengan hasil wawancara menunjukkan bahwa S3 dapat menuliskan dan menyebutkan unsur-unsur yang diketahui dan ditanyakan pada soal. Pada proses tes, S3 tidak menuliskan ide/gagasan penyelesaian masalah, tetapi dapat menyebutkan satu ide dalam proses wawancara.

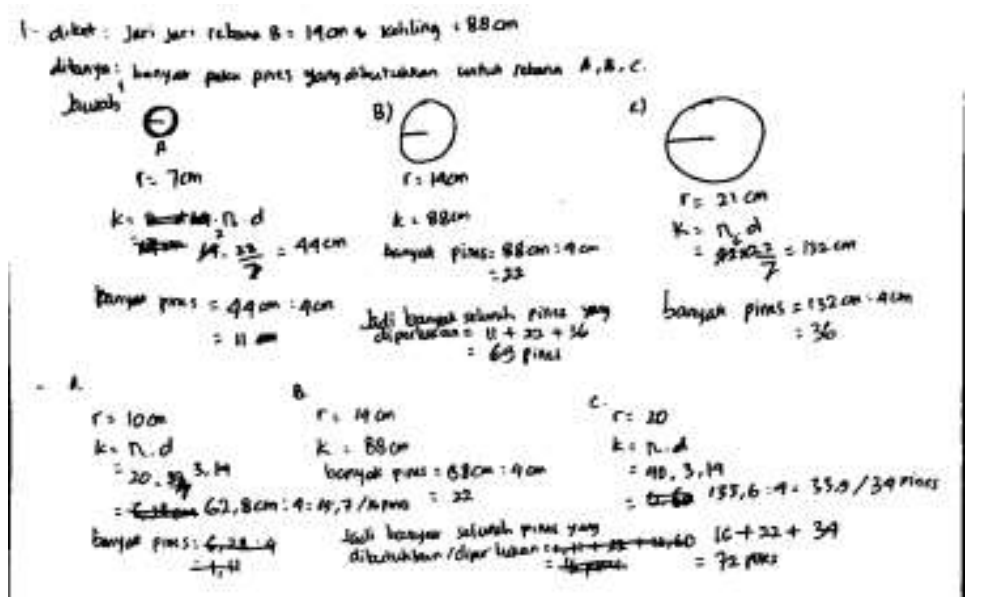

Gambar 7. Hasil tes S3 pada soal nomor 1 
Ide yang diberikan adalah menentukan jari-jari rebana $A$ dan $C$, menghitung keliling rebana $A$ dan $C$, menentukan banyak pines yang dibutuhkan masing-masing rebana, serta menjumlahkan banyak pines yang dibutuhkan untuk semua rebana. Proses penyelesaian dapat dilakukan dengan 2 strategi, yaitu : (1) menggunakan rebana $A$ dengan jari-jari 7 satuan dan rebana $C$ dengan jari-jari 21 satuan; (2) menggunakan rebana $A$ dengan jari-jari 10 satuan dan rebana $C$ dengan jari-jari 20 satuan; dan (3) menggunakan rebana $A$ dengan jari-jari 7 satuan dan rebana $C$ dengan jari-jari 30 satuan. S3 memilih nilai jari-jari tersebut dengan asumsi dapat menggunakan nilai $\pi=\frac{22}{7}$ atau $\pi=3,14$. Di akhir proses tes dan wawancara menunjukkan bahwa S3 dapat menuliskan dan menyebutkan penyelesaian masalah dengan kalimatnya sendiri.

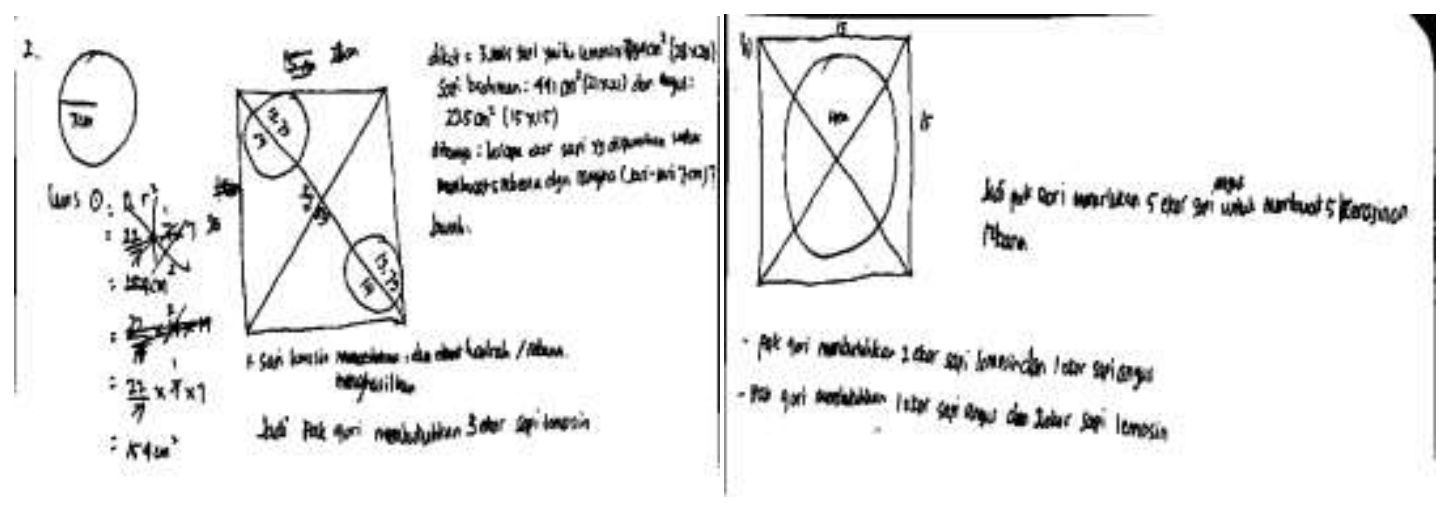

Gambar 8. Hasil tes S3 pada soal nomor 2

Gambar 8 menunjukkan penyelesaian tes S3 pada masalah kedua. Triangulasi hasil tes dan hasil wawancara menunjukkan bahwa S3 dapat mengidentifikasi unsurunsur yang diketahui dan ditanyakan dari masalah yang diberikan melalui tes dan wawancara. S3 tidak dapat menuliskan ide yang akan digunakan untuk menyelesaikan masalah dalam proses tes. Tetapi dalam proses wawancara, S3 dapat menyebutkan satu ide penyelesaian masalah, yaitu mencari luas alat hadrah kemudian menentukan kulit yang sesuai dengan hadrah tersebut. Pada proses tes dan wawancara, S3 dapat memberikan 3 strategi penyelesaian, yaitu penggunaan 5 kulit sapi Limousin, atau 5 kulit sapi Angus, atau 2 kulit sapi Limousin dan 1 kulit sapi Angus. Pada tes maupun wawancara, S3 dapat menjelaskan hasil penyelesaian masalah dengan menggunakan kalimat sendiri.

Berdasarkan hasil yang telah diperoleh, maka dapat diketahui bahwa pada indikator pertama ketiga subjek dapat menuliskan unsur-unsur yang diketahui dan ditanyakan berdasarkan masalah yang diberikan dengan kalimatnya sendiri. Hal tersebut diperkuat dengan hasil wawancara ketiga subyek yang lancar dalam menjelaskan unsur-unsur yang diketahui maupun yang ditanyakan. S1 membutuhkan waktu kurang lebih 8 menit untuk memahami soal dan mengidentifikasi unsur-unsur yang dibutuhkan untuk penyelesaian masalah. S2 membutuhkan waktu kurang lebih 10 menit untuk mengidentifikasi unsur-unsur yang diketahui dan ditanyakan dalam soal. S3 membutuhkan waktu paling lama dari subjek lainnya, yaitu kurang lebih 13 menit untuk memahami isi soal dan mendapatkan unsur-unsur yang dibutuhkan untuk menyelesaikannya. 
Pada indikator kedua tentang kemampuan membuat dan menyusun model matematika dari masalah yang diberikan, menunjukkan bahwa ketiga subjek tidak ada yang menuliskan ide atau gagasan dalam proses tes. Tetapi dalam proses wawancara diketahui bahwa setiap subjek memiliki dan dapat menjelaskan ide atau gagasannya. Setiap subjek memiliki satu ide/gagasan untuk penyelesaian masalah yang akan dilakukan. Untuk itu dapat dikatakan bahwa ketiga subjek belum dapat memenuhi indikator kedua.

Pada indikator ketiga tentang kemampuan menyusun strategi atau bermacammacam pendekatan untuk penyelesaian masalah, menunjukkan bahwa pada soal pertama ketiga subjek dapat memberikan masing-masing tiga strategi penyelesaian masalah. Pada soal kedua, S1 dan S2 dapat memberikan masing-masing tiga strategi, sedangkan S3 hanya dapat memberikan dua strategi penyelesaian. Berdasarkan pembahasan tersebut dapat dikatakan bahwa S1 dan S2 telah memenuhi indikator ketiga, namun S3 belum maksimal dalam memenuhi indikator ketiga.

Indikator keempat tentang kemampuan menjelaskan hasil penyelesaian masalah sesuai permasalahan awal dengan kalimat sendiri. Hasil penelitian menunjukkan bahwa ketiga subjek mampu menjelaskan hasil penyelesaian masalah sesuai dengan permasalahan awal dengan kalimat sendiri. Untuk itu dapat dikatakan bahwa ketiga subjek dapat memenuhi indikator keempat.

Kondisi ketiga subjek menunjukkan bahwa tahapan penyelesaian masalah telah dilakukan oleh subjek walaupun pada indikator pembuatan dan penyusunan model matematika dari masalah yang diberikan masih belum tampak dalam proses tes. Hal ini sesuai dengan hasil penelitian Yuwono, Supanggih, dan Ferdiani (2018) bahwa pada tahap perencanaan subjek penelitian tidak menuliskan rencana penyelesaian masalah tetapi memahami cara yang akan mereka lakukan. Sedangkan pada kemampuan penyelesaian masalah menunjukkan bahwa subjek baru dapat membuat satu ide/gagasan namun dapat menunjukkan strategi penyelesaian masalah yang beragam. Artinya ide budaya yang dimasukkan dalam masalah matematika tersebut dapat dipahami oleh subjek, walaupun hanya dapat memunculkan satu ide/gagasan namun dapat menghasilkan strategi penyelesaian yang beragam.

Keberadaan ide budaya dalam masalah matematika menunjukkan bahwa etnomatematika dapat diintegrasikan dalam pembelajaran, salah satunya seperti dalam pembuatan instrumen penyelesaian masalah. Instrumen penyelesaian masalah merupakan bagian dari bahan ajar. Penelitian terdahulu yang dilakukan oleh Dahlan dan Permatasari (2018) juga menunjukkan bahwa bahan ajar berbasis etnomatematika pada topik himpunan mampu memfasilitasi siswa dalam mengkonstruksi pengetahuan matematika secara induktif. Hasil penelitian Sudirman, Son, dan Rosyadi (2018) juga menunjukkan bahwa motif batik Paoman Indramayu yang memuat konsep geometri, dapat digunakan dalam pembelajaran di Sekolah Dasar pada materi pengenalan garis, sudut, dan bangun datar sederhana.

Selain hasil yang diharapkan sesuai indikator ketercapaian, hasil penelitian ini juga menunjukkan adanya temuan yang menarik. Temuan pertama adalah adanya variasi cara subjek menuliskan ekspresi matematis dari suatu ide. Variasi tersebut dijumpai pada S1 dan S3 dalam menggambarkan satu bentuk rebana dan kulit yang disatukan untuk menyelesaikan masalah. Sedangkan S2 menuliskan ekspresi matematikanya dengan menggambar satu-persatu rebana dan kulit untuk menjawab soal tes. Temuan kedua terkait cara subjek menyebutkan proses penyelesaian masalah Open-Ended. Subjek tidak menggunakan konsep luas untuk menyelesaikan 
masalah, tetapi menggunakan konsep unsur-unsur lingkaran yang berupa jari-jari dan diameter yang dihubungkan pada kulit yang digambarkan dalam bentuk persegi. Temuan-temuan tersebut dapat menjadi kajian lebih lanjut yang menarik dalam pengembangan penelitian ini.

\section{SIMPULAN DAN SARAN}

Berdasarkan hasil dan pembahasan yang diperoleh, dapat disimpulkan etnomatematika Hadrah Al-Banjari dapat dijadikan sebagai basis pembuatan instrumen penyelesaian masalah open-ended. Masalah yang diberikan kepada subjek terkait dengan konsep keliling dan luas lingkaran. Hasil analisis data menunjukkan bahwa subjek mampu : (1) mengidentifikasi unsur-unsur yang diketahui dan ditanyakan untuk penyelesaian masalah; (2) membuat dan menyusun model matematika dari masalah yang diberikan dengan satu ide/gagasan; (3) menyusun minimal tiga strategi atau pendekatan untuk menyelesaikan masalah sesuai waktu yang diberikan; serta (4) menjelaskan hasil penyelesaian masalah sesuai permasalahan awal dengan kalimat sendiri. Berbagai temuan dan kekurangan dalam penelitian ini memberikan gambaran bahwa saran untuk penelitian selanjutnya dapat dilakukan dengan mengembangkan instrumen-instrumen berbasis etnomatematika dari berbagai budaya, khususnya yang ada di Banyuwangi.

\section{DAFTAR PUSTAKA}

Afriyanty, M., dan Izzati, N. 2019. Eksplorasi Etnomatematika pada Corak Alat Musik Kesenian Marawis sebagai Sumber Belajar Matematika. Jurnal Gantang, Vol. 4(1) : 39-48.

Dahlan, J. A., dan Permatasari, R. 2018. Pengembangan Bahan Ajar Berbasis Etnomatematika dalam Pembelajaran Matematika Sekolah Menengah Pertama. JNPM (Jurnal Nasional Pendidikan Matematika), Vol. 2(1): 133-150.

Djahuno, S. 2015. Pengembangan Soal-Soal Open-Ended pada Pokok Bahasan Barisan dan Deret Bilangan di Kelas IX A SMP Negeri 2 Tolitoli. Jurnal Kreatif Tadulako Online, Vol. 4(6) : 272-280.

Hariastuti, R. M., Budiarto, M. T., dan Manuharawati. 2020. Incorporating Culture and Mother Tongue in Mathematics Learning : Counting Operation in Traditional Houses Using Banyuwangi. Malikussaleh Journal of Mathematics Learning, Vol. 3(2) : 62-69.

Khoiri, A. 2019. Dakwah Melalui Seni Musik Seni Islam Religi (Kajian Kelompok Hadrah musik Religi Al-Banjari Al- Zam Zam MAN 1 Tanggerang). Skripsi tidak diterbitkan. Banten: Universitas Islam Negeri Sultan Maulana Hasanuddin.

Machrus, J. 2014. Hadrah Al-Banjari: Studi Tentang Kesenian Islam di Bangil. Skripsi tidak diterbitkan. Surabaya: Universitas Islam Negeri Sunan Ampel.

Mairing, J. P. 2016. Kemampuan Siswa Kelas VIII dalam Memecahkan Masalah Matematika Berdasarkan Tingkat Akreditasi. Jurnal Kependidikan, Vol. 46(2) : 179-192.

Mairing, J. P., dan Aritonang, H. 2018. Penyelesaian Masalah Matematika Berakhir Terbuka pada Siswa SMA. Jurnal Pendidikan Matematika, Vol. 4(1) : 60-61. 
Mustikasari, Zulkardi, dan Aisyah, N. 2010. Pengembangan Soal-soal Open-Ended Pokok Bahasan Bilangan Pecahan di Sekolah Menengah Pertama. Jurnal Pendidikan Matematika, Vol. 4(1) : 45-60.

Nada, I. 2018. Penerapan Model Open-Ended Problems Berbantuan Compact Disk (CD) Pembelajaran untuk Meningkatkan Kemampuan Berpikir Kreatif Siswa Kelas IV SD 1 Golantepus. Jurnal Pendidikan Sekolah Dasar (JPsd), Vol. 4(2) : 9-38.

Polya, G. 1973. How to Solve It, A New Aspect of mathematical Method. New Jersey: Princenton University Press.

Putri, L. I. 2017. Eksplorasi Etnomatematika Kesenian Rebana sebagai Sumber Belajar Matematika pada Jenjang MI. Jurnal Pendidikan Dasar, Vol. 4(1) : 2131.

Ramadhani, P. 2019. Analisis Etnomatematika Kesenian Rebana Sebagai Sumber Belajar Matematika Bagi Siswa SMP Darul Falah Bandar Lampung. Skripsi tidak diterbitkan. Lampung: Universitas Islam Negeri Raden Intan.

Rianti, R. 2018. Profil Kemampuan Pemecahan Masalah Matematis Siswa SMP pada Materi Bangun Ruang Sisi Datar. Jurnal Pendidikan Tambusai, Vol. 2(4) : 802-812.

Ruslan, A. S. dan Santoso, B. 2013. Pengaruh Pemberian Soal Open-Ended Terhadap Kemampuan Penalaran Matematis Siswa . Jurnal Kreano, Vol. 4(2): 138-150.

Sa'diah, H. 2019. Analisis Kemampuan Menyelesaikan Soal Matematika Berdasarkan Teori Polya Materi Aritmetika Sosial Siswa kelas VII SMP Negeri 2 Kauman Tulungagung. Skripsi tidak diterbitkan. Tulungagung: Institut Agama Islam Negeri Tulungagung.

Sudirman, Son, A. L., dan Rosyadi. 2018. Penggunaan Etnomatematika pada Batik Paoman dalam Pembelajaran Geomteri Bidang di Sekolah Dasar. Indomath: Indonesia Mathematics Education, Vol. 1(1) : 27-34.

Sumartini, T. S. 2016. Peningkatan Kemampuan Pemecahan Masalah Matematis Siswa melalui Pembelajaran Berbasis Masalah. Jurnal Mosharafa, Vol. 5(2) : $148-158$.

Suryanovan, H. 2014. Pengaruh Pembelajaran dengan Pendekatan Open-Ended terhadap Peningkatan Kemampuan Berpikir Kreatif dan Disposisi Matematis Siswa. Jurnal Pendidikan Matematika Universitas Lampung, Vol. 2(4) : 13-23.

Syutaridho, M. 2015. Pengembangan Soal Open-Ended pada Pokok Bahasan Pythagoras. Jurnal Pendidikan Matematika RAFA, Vol.1(1) : 118-139.

Yusliriadi, D. S. 2015. Pengembangan Soal Open-Ended Pokok Bahasan Barisan dan Deret Bilangan untuk Siswa SMP. Jurnal Elemen, Vol. 1(2) : 106-118.

Yuwono, T., Supanggih, M., dan Ferdiani, R. D. 2018. Analisis Kemampuan Pemecahan Masalah Matematika dalam Menyelesaikan Soal Cerita Berdasarkan Prosedur Polya. Jurnal Tadris Matematika, Vol. 1(2) : 137-144. 